\title{
ICT use in the teaching of mathematics: Implications for professional development of pre-service teachers in Ghana
}

\author{
Douglas D. Agyei • Joke Voogt
}

Published online: 17 August 2010

C The Author(s) 2010. This article is published with open access at Springerlink.com

\begin{abstract}
Included in the contemporary mathematics curricula in Ghana is the expectation that mathematics teachers will integrate technology in their teaching. However, importance has not been placed on preparing teachers to use ICT in their instruction. This paper reports on a study conducted to explore the feasibility of ICT use in mathematics teaching at senior high school levels in Ghana. Interviews and survey data were used for data collection. Preliminary results showed that mathematics teachers in Ghana do not integrate ICT in their mathematics instruction. Among the major perceived barriers identified were: Lack of knowledge about ways to integrate ICT in lesson and Lack of training opportunities for ICT integration knowledge acquisition. To overcome some of these barriers, opportunities of a professional development arrangement for pre-service mathematics teachers were explored. Findings from the study revealed specific features of a professional development scenario that matters for ICT integration in mathematics teaching in the context of Ghana.
\end{abstract}

Keywords ICT use - Professional development - Computer competencies · Mathematics education $\cdot$ Computer attitude $\cdot$ Ghana

\section{Introduction}

In Ghana, mathematics is a compulsory subject at all levels in pre-university education. Due to its importance the government is committed to ensuring the provision of high quality mathematics education. Various attempts have been made

D. D. Agyei $(\triangle)$

School of Physical Sciences, Department of Mathematics \& Statistics, University of Cape Coast, Cape Coast, Ghana

e-mail: d.d.agyei@utwente.nl

J. Voogt

Department of Curriculum Design and Educational Innovation, University of Twente, P.O. Box 217, 7500AE Enschede, The Netherlands

e-mail: j.m.voogt@utwente.nl 
in the past to improve the achievement of mathematics in schools. The most recent is seen in the New Educational Reforms (Anamuah-Mensah National Education Review Committee Report 2002) of which implementation started in September, 2007. The new curriculum in Mathematics at the Senior High School (SHS) places emphases on skill acquisition, creativity and the arts of enquiry and problem solving. It aims at developing in the student the ability and willingness to perform investigations using various mathematical ideas and operations. As part of the reforms the curriculum places a lot of emphasis on Information and Communication Technology (ICT) as a tool for teaching mathematics (MOESS 2007). It is therefore, designed to meet expected standards of mathematics in many parts of the world. In spite of government efforts, mathematics has not undergone much change in terms of how it is presented. These reflect consistently in low achievement levels in mathematics among students at the high school levels. Results from the Trends in International Mathematics and Science Study (TIMSS) in 2003 and 2007 at the junior high school level (grade 8 equivalents) are instances of poor mathematics achievement in the country. In the aforementioned study, Ghana's eighth graders were ranked 43rd among 44th and 46th among 47 countries that participated in the study in 2003 and 2007 respectively (Mullis et al. 2004, 2008). The situation is not too different in SHS's. For many years the failure rate in mathematics has been dramatically high in SHS's. The low scores of students' over the years in the Senior Secondary School Certificate Examination attest to this (Ottevanger et al. 2007). In Ghana not many studies have been conducted to explain such poor students' performance in mathematics. Ampiah et al. (2004) reported that both pre-service and in-service programmes in mathematics predominantly reflect teacher-centred approaches to learning. Curriculum documents in this context suggest that teachers should start every lesson with a practical problem to help students acquire the habit of analytical thinking and the ability to apply knowledge in solving practical problems (MOE 2000) and also make use of the calculator and the computer for problem solving and investigations of real life situations (MOESS 2007), but this orientation to teaching and learning requires more than recommendations contained in syllabuses. More particularly the report on Developing Science, Mathematic and ICT (SMICT) education in Sub-Saharan Africa suggested changes to the teacher's instructional role from presenter of knowledge and the use of drill-oriented methods to participatory teaching and learning (Ottevanger et al. 2007). On a much broader note, research conducted in other Sub-Saharan Africa highlights some of the factors responsible for poor students' achievement in mathematics: poorly-resourced schools; large classes; a curriculum hardly relevant to the daily lives of students; a lack of qualified teachers; and inadequate teacher education programmes (Ottevanger et al. 2007). The government of Ghana recognizes the need for teacher support for mathematics teachers in various ways. He considers ICT literacy as an engine for accelerated development outlined in the Ghana Information and Communication Technology for Accelerated development (Ghana ICT4AD Policy document 2003). Ghana introduced ICT into the school curriculum in September 2007 following the recommendations of the ICT4AD document and the AnamuahMensah National Education Review Committee Report (2002). Both documents highlight the importance of integrating ICT into the curriculum at all levels. As a result, the government and other institutions have invested huge sums of money in 
procurements of computers and establishment of computer labs in most SHS's, but it is still unclear whether these computers are being used effectively by teachers in their instruction. Thus the question of whether mathematics teachers need any further support to be able to integrate effectively the use of ICT in their daily teaching routines remains unanswered. The overall goal of the present study was to explore the feasibility of ICT use in mathematics classrooms in Ghana as part of an ongoing research project to design a professional development programme for pre-service teachers. The relevance of this study was to (1) provide an understanding of the context of mathematics teachers in the SHS's in Ghana regarding ICT integration in mathematics lessons and (2) determine the features of an ICT intervention that fits the realities in the SHS's that can prepare pre-service teachers to effectively design and implement ICT in teaching mathematics. The study was guided by the following questions:

1. What are the barriers of ICT use in teaching mathematics in SHS's in Ghana?

2. What are the needs of pre-service and in-service mathematics teachers in teaching mathematics with ICT in SHS's in Ghana?

3. What are the opportunities of ICT use in the teaching of mathematics in SHS's in Ghana?

\subsection{Teacher preparation programmes for teaching mathematics in the Senior High} School

The SHS mathematics curriculum in Ghana focuses on attaining one crucial goal: to enable all Ghanaian young persons to acquire the mathematical skills, insights, attitudes and values that they will need to be successful in their chosen careers and daily lives (MOESS 2007). This curriculum is based on the premises that all students can learn mathematics and that all need to learn mathematics. It builds on the knowledge and competencies developed at the Junior High School level, placing a lot of emphases on the development and use of basic mathematical knowledge and skills. The student is expected at the SHS level to develop the required mathematical competencies to be able to use his/her knowledge in solving real life problems and secondly, be well equipped to enter into further study and associated vocations in mathematics, science, commerce, industry and a variety of other professions (MOESS 2007). The rationale of the curriculum has therefore a lot of implications on teaching strategies and the training of mathematics teachers for SHS's. In Ghana Mathematics Teacher education for Senior High Schools is offered by two main institutions, the University of Cape Coast (UCC) and University of Education, Winneba (UEW). These two universities are institutes for higher education that have the specific task to train teachers for the SHS's. The main route in the teacher education at both UCC and UEW is the Bachelor of Education qualification of 4 years duration. Three main components are present in these programmes: subject content courses, education courses and teaching practice. The education courses are further sub-divided into general ones and subject-specific ones (i.e. for individual school subjects, or categories of subjects like science). The latter are taught in the science and mathematics education departments and denoted as science or mathematics pedagogy courses. The general education courses are taught in other education departments, mostly Education Foundations. Similarly for teaching 
practice placement in schools, the organisation is done by a general education department for all students from various subjects. A major difference between the two universities lies in the fact that most content in UCC is taught by the Faculty of Science, whilst at UEW this takes place in the Faculty of Science Education. The mathematics content courses (which cover the SHS curricula) at the first and second year undergraduate level are the main basis for teacher education students, but some further content courses at the third and fourth year levels are also in the programme. Two main problems can be distinguished that put the quality of the programmes under pressure; reduced opportunities for interaction between lecturers and individual students (as a result of fast expansion of student numbers in universities) and lack of practical orientation. The later has roots in the educational tradition of the Ghana education system which emphasizes teacher-centred exposition as a main educational method (Adu-Gyamfi and Smit 2007).

\subsection{Potential of ICT for mathematics education}

The use of ICT in the mathematics classroom has long been a topic for consideration by mathematics educators. Some examples of ICT use in mathematics include: portables, graphic calculators and computerized graphing, specialised software, programmable toys or floor robots, spreadsheets and databases. Studies have shown that a range of portable devices exists which allow pupils to collect data, and manipulate it using spreadsheets and databases for work in numeracy. Some portable equipment also enables the study of maths to move out of the classroom and to incorporate fieldwork investigations (Moseley and Higgins 1999). The use of graphic calculators and computerized graphing in mathematics speeds up the graphing process, freeing people to analyse and reflect on the relationships between data (Hennessy 2000; Clements 2000; Hennessy et al. 2001). Specialists software such as Computer Algebra Systems (CAS), Dynamic Geometry Systems (DGS) and Maths curriculum software improve pupils' skills and understanding in algebra, allow pupils to manipulate and measure shapes leading to higher level of learning among them (Hennessy et al. 2001; Clements 2000). Programmable toys or floor robots controlled by instructions in programming languages (usually Logo) were one of the earliest applications of ICT to maths, and where used were the cause of significant changes in maths teaching (Becta 2003). Logo encourages pupils to develop problem-solving skills, leads them to develop higher levels of mathematical thinking as well as learn geometric concepts (Clements 2000). According to Ittigson and Zewe (2003) ICT supports constructivist pedagogy, which allows students explore and reach an understanding of mathematical concepts. This approach promotes higher order thinking and better problem solving strategies (Ittigson and Zewe 2003). Becta (2003) reiterated that teachers can maximize the impact of ICT in maths teaching by using ICT as a tool in working towards learning objectives. For mathematics educators, defining the most effective uses of ICT in the teaching of mathematics can certainly be described as a "wicked problem," as represented by Mishra and Koehler (2006). A number of challenging instructional questions are associated within this wicked problem, such as: When should teachers incorporate calculators when teaching arithmetic? How should teachers incorporate the powerful new symbolic programs within basic algebra instruction? Should teachers allow 
student use of the many new online homework assistance web sites for mathematics? Such instructional questions illustrate that the problem of effective ICT integration into the teaching of mathematics is a complex innovation for teachers. They do not only need to have competent knowledge of teaching mathematics but also need to be competent in the pedagogical use of ICT (AACTE 2008; Voogt 2008).

\subsection{Factors inhibiting ICT use in mathematics classrooms}

Many studies have shown several obstacles that teachers experience in the integration of ICT in their classrooms. Jones (2004) found a number of barriers for the integration of ICT into lessons: (1) lack of confidence among teachers during integration, (2) lack of access to resources, (3) lack of time for the integration, (4) lack of effective training, (5) facing technical problems while the software is in use, (6) lack of personal access during lesson preparation and (7) the age of the teachers. Snoeyink and Ertmer (2002) have identified these or similar variations as widespread barriers: lack of computers, lack of quality software, lack of time, technical problems, teacher attitudes towards computers, poor funding, lack of teacher confidence, resistance to change, poor administrative support, lack of computer skill, poor fit with curriculum, scheduling difficulties, poor training opportunities, and lack of vision as to how to integrate ICT in instruction. A study (Agyei and Voogt, submitted) conducted in Ghana among pre-service and in-service mathematics teachers explored the influence of computer attitudes, competencies and access of the teachers on their levels of ICT integration using the will, skill and tool concept. The study reported low levels of ICT integration levels as a result of low competencies and access levels of ICT. Furthermore, the study showed fairly high levels of positive computer attitudes and indicated among others to be a necessary condition to prepare teachers for new teaching methods which are flexible and involve appropriate use of ICT. Of equal importance to ICT integration is teacher preparation programmes. Research have shown that such programmes have not adequately modelled the use of technology in their method courses (Adamy and Boulmetis 2006) or incorporated effective approaches to technology integration into a single technology courses (Brown and Warschauer 2006).

\section{Method}

\subsection{Participants}

A total of 180 educators constituting of 60 in-service mathematics teachers and 120 pre-service mathematics teachers participated in the study. Mathematics teachers were used in the study because the mathematics curriculum in particular emphasizes the use of ICT in the teaching and learning process. The practicing teachers were selected from 16 Senior High Schools (SHS) ranging from government, mission, private and international schools. Schools were selected because they had a reasonable number of mathematics teachers as well as some kind of ICT infrastructure. The average age of these in-service teachers was approximately 39 ranging between 25 and 59 years. There were 52 males and only 8 females. The 
average teaching experience was approximately 12 years ranging from as low as 1 year to 37 years. The pre-service mathematics teachers were from the mathematics teacher education programme at University of Cape Coast (UCC), Ghana. 95 of them were males and 25 females aged between 19 and 43 years with an average age of nearly 26 years. The low representation of female teachers in this study is a reflection of the under-representation of females in science and mathematics in particular at all levels, from basic school to university. For instance, in 2006, female teachers constituted only $15 \%$ of the mathematics teachers in the country (Ottevanger et al. 2007). Six Principals and 14 Heads of departments (Hod's) in the mathematics section from the 16 SHS's were involved in the study. Also involved in the study were the Head of department of the teacher education programme and an officer from the ICT section of the Ghana Education Service (GES).

\subsection{Research instruments}

\subsubsection{Questionnaire}

A questionnaire was used to collect data for this study. The first section of the questionnaire was used to collect demographic data. Following this were sections about availability and levels of ICT access, current pedagogical practices, perceived barriers in the use of ICT, and professional development and training needs.

Availability and accessibility of ICT Variables indicating level of availability and accessibility of ICT facilities were used to measure ICT infrastructure available and also accessible by in-service mathematics teachers in the SHS. Respondents were supposed to indicate either "yes" or "no" to whether they had a facility available/ accessible in their various schools.

Current pedagogical practices, perceived barriers in the use of ICT, and professional development and training needs Different variables were used to measure the current practices of in-service mathematics teachers from the SHS's and the instructors at the teacher education programme at UCC. Barriers teachers perceived in the use of ICT in instruction and perceptions of professional developments and training needs were also measured.

\subsubsection{Interviews}

Interviews were conducted for 6 principals and 14 Hod's from the SHS's that were involved in the study. Interview data was meant to provide in-depth elaborations for data collected through the questionnaire.

\subsection{Data collection and data analysis procedures}

The questionnaire was distributed to the pre-service teachers during the school after a lecture. For the in-service teachers it was sent to them in their various high schools 
with the help of principals and department heads. To analyze the data descriptive statistics was used. Interview data were audio taped and transcribed using data reduction technique (Miles and Huberman 1994).

\section{Results}

\subsection{Barriers to ICT integration}

\subsubsection{Perceived barriers to ICT integration}

What was perceived to be important barriers in integrating ICT in lessons was investigated in the study. Respondents were asked to indicate their levels of agreement on perceived barriers to ICT integration on a five-point Likert scale $(1=$ strongly disagree, $5=$ strongly agree). The scores were interpreted as follows: one is the lowest possible score, which represents a negative attitude, while five is the highest possible score which represent a very strong positive attitude. Table 1 shows the mean values of the barriers as perceived by the teachers. The first two perceived barriers reported by the respondents centred on teachers' lack of ICT knowledge in integration: Lack of knowledge about ways to integrate ICT in lessons (in-service teachers $=3.88$, pre-service teachers $=4.28$ ) and Lack of training opportunities for ICT integration knowledge acquisition (in-service teachers $=3.87$, pre-service teachers $=4.18$ ). Lack of ICT infrastructure (in-service teachers $=3.80$, pre-service teachers $=4.17$ ) was also considered a barrier perceived high by the teachers (the following section elaborate further on the status of ICT infrastructure in the schools). The least identified perceived barrier was: Schools are not interested in integrating ICT in curriculum (in-service teachers $=2.18$, pre-service teachers $=2.12$ ), which suggested that most SHS's embrace the idea of integrating ICT in teaching

Table 1 Perceived barriers to ICT integration by in-service and pre-service teachers $(N=180) ; M, S D$, Cronbach's Alpha: In-service teachers $=0.82$, Pre-service teachers $=0.80$

\begin{tabular}{llllll}
\hline Perceived barrier & \multicolumn{2}{l}{$\begin{array}{l}\text { In-service } \\
(n=60)\end{array}$} & $\begin{array}{l}\text { Pre-service } \\
(n=120)\end{array}$ \\
\cline { 2 - 5 } & M & $S D$ & $M$ & $S D$ \\
\hline Lack of technical support regarding ICT integration & 3.77 & 1.24 & 4.09 & 1.00 \\
Lack of support from administration & 3.48 & 1.32 & 3.93 & 1.17 \\
Lack of knowledge about ways to integrate ICT in lessons & 3.88 & 1.21 & 4.28 & 1.02 \\
Lack of training opportunities for ICT integration knowledge acquisition & 3.87 & 1.07 & 4.18 & 0.89 \\
Schools are unsure as to how effectively to integrate ICT in teaching & 3.67 & 1.07 & 3.78 & 1.23 \\
Teachers do not have sufficient time to integrate ICT & 3.52 & 1.20 & 3.71 & 1.22 \\
Lack of ICT infrastructure (i.e. computers, computer lab, internet) in schools & 3.80 & 1.31 & 4.17 & 1.13 \\
Schools are not interested in integrating ICT in curriculum & 2.18 & 1.05 & 2.12 & 1.22 \\
Curriculum does not allow enough time to integrate ICT in teaching & 3.75 & 1.10 & 3.54 & 1.40 \\
\hline
\end{tabular}


mathematics. In general the mean values for the pre-service teachers appear to be higher than the in-service teachers, but the differences were not huge.

\subsubsection{Availability and accessibility of ICT}

To ascertain the current situation in the SHS's, the 60 in-service teachers were asked if certain ICT facilities were available. Table 2 gives a summary of their responses. About $98 \%$ of the in-service teachers from the 16 SHS reported having at least one computer laboratory in their schools.

The high responses in the availability of computer labs were confirmed by the officer from the ICT unit of the GES. In an interview with him, he reported that the Government of Ghana is committed to deployment of sufficient ICT infrastructure in all SHS's in Ghana. He purported "As part of the New Reforms to introduce ICT at all level of Education in Ghana, it is the Governments' policy to provide ICT facility in all SHS. Some schools have already taken delivery of such support while the process is still ongoing". Some teachers also indicated that Parents-Teachers Association (PTA) had been helpful in providing computers in their schools. This apparently explains the establishments of computer lab(s) in all the schools. Further questions were asked to ascertain how accessible these facilities were. Relatively low figures: (Access to Computers (office/Computer Lab) $=21 \%$, Access to Computers $($ staff common room/Library) $=13 \%$ and Internet Connectivity $=46 \%$ ) indicating low accessibilities of computer facilities were observed. The teachers indicated further that computer laboratories were used mainly for Information Technology (IT) lessons which were compulsory for all students; making it difficult to access facilities in computer lab for personal use or other purposes. Interview data from the Hod's and the principals of the various SHS's gave a better picture of the state of ICT availability and accessibility in the schools. The interview data (by the Hod's) indicated that schools lacked specialised software application (e.g. as derive, graphic calculus, geometer's sketchpad etc) and did not use them at all in classrooms. Most of the Hod's (12 out of 14) confirmed that computer labs were mostly used by the IT departments to train students to acquire basic skills in computing and were not used for any other subject instruction. However, six of them pointed further that, the facility was available to all interested teachers (mainly after school) to prepare their lessons and also get information from the internet. One of the Hod's said that his school had a specialised Lab just for the teachers to enhance their preparation for a

Table 2 Availability of ICT facilities in SHS's $(N=60)$

\begin{tabular}{lr}
\hline ICT Facility & $\%$ yes \\
\hline Computer Laboratory & 98 \\
Computers in the Library & 40 \\
Computers in the Staff common room & 20 \\
Computers in the mathematics department (office) & 15 \\
Computer in your office & 23 \\
Internet connectivity & 47 \\
\hline
\end{tabular}


lesson. Responding to the question whether the Lab could be used for mathematics lessons with their students, seven were of the view that it was possible to arrange to use the facility while the other seven said the lab was almost always busy. One of them had the following to say: "Normally the time table is structured in such a way that it will be difficult for any other subject teaching in the Lab; because of the number of classes the Lab is always occupied. More computer Labs should be created so that other subject teaching could be possible." and the other: "Hitherto mathematics teachers have not been using computers in their instruction so no such arrangement had been made, but with effort and planning with the IT unit it should be feasible". All the principals on the other hand maintained strongly that any teacher who was willing to use the lab for a lesson could make an arrangement for it. One of them commented as below: "This is a facility that is made available for teaching. As an IT department it beholds on them to train the students in the use of the facility; but if a mathematics teacher wants to use the facility for his/her lesson, it is also available. Yes. So we use them interchangeably. The idea that the school must equip the students to acquire basic IT skills is one side, the teachers also willing to use it in their individual lesson is another side". Another head asserted: "The facilities are there; but the problem is with the teacher. The teacher should be in the position to use them. If the teachers are well equipped then they can integrate ICT in their teaching. The teachers being well equipped is a very crucial condition for student to benefit fully from the facilities".

\subsubsection{Current pedagogical practices}

Both in-service and pre-service teachers responded to this item, citing the teaching strategies they use and that which they have experienced in their SHS's respectively. In Table 3, list of teaching routines that teachers carry out or were experienced are presented.

The results showed that the most frequently used teaching strategy in the SHS's is the "Chalk and Talk" approach (Lecture Method) (in-service $=3.33$, pre-service $=$ 3.35). Interview data confirmed this. All the Hod's stated emphatically during the interview that it was the main approach used by teachers in their departments. They explained that the approach allows the teachers to quickly convey lots of information

Table 3 Teaching strategies used in SHS's $(\mathrm{N}=180)$ : $(M, S D)$

\begin{tabular}{lccccc}
\hline Teaching Strategy & \multicolumn{2}{l}{ In-service Teachers(n=60) } & & \multicolumn{2}{l}{ Pre-service Teachers (n=120) } \\
\cline { 2 - 3 } \cline { 5 - 6 } & $\mathrm{M}$ & & $\mathrm{M}$ & & $\mathrm{SD}$ \\
\hline Chalk and talk approach & 3.33 & 0.97 & & 3.35 & 0.90 \\
Use of handouts/pamphlet & 2.57 & 1.03 & & 2.09 & 0.93 \\
Individual assignments & 2.85 & 0.80 & & 2.62 & 0.78 \\
Use of group/team work & 2.30 & 0.81 & & 1.92 & 0.74 \\
Use of ICT & 1.57 & 0.90 & & 1.38 & 0.62 \\
Use of demonstrations & 2.48 & 0.93 & & 2.12 & 0.83 \\
\hline
\end{tabular}

$1=$ Never, 2 Sometimes, $3=$ often, $4=$ Nearly always, $M$ Mean, $S D=$ Standard Deviation 
to students because teachers do most of the talking and giving out of notes while students copy the notes. In so doing, they are able to cover a lot of topics in the curriculum before the students write their examinations. Two Hods' said mathematics teachers in their department occasionally gave assignments to students in groups to read on various topics to do individual presentations and one other said maths teachers in his department used demonstrations and experiments especially when teaching probability to their students. Table 3 shows that the "Use of ICT" is the teaching strategy which is the least used (in-service teachers $=1.57$, pre-service teachers =1.38). One of the interviewees' purported; "We are not yet there. At best some mathematics teachers are able to type their own questions for student tests and examinations. They are able to get information they need from the internet either for their own purposes or to prepare their notes". Responses depicted in Table 3, seem to suggest a similar trend for both group of teachers although the mean values for pre-service teachers were relatively low.

\subsubsection{Levels of ICT use at the teacher education programme in UCC}

With regards to ICT application in instruction, pre-service teachers were asked to indicate the extent to which instructors in their department applied some ICT applications in teaching. They had to indicate one of these stages: (1) Not at all; (2) A little;(3) Somewhat and (4) A lot. Table 4 reveals that instructors (Mean $=1.32$, $\mathrm{SD}=0.73$ ) in the department do not make use of ICT applications at all or at best just a little in their instruction.

The Head of Department of the mathematics education programme reiterated this in an interview. He indicated that most of the content courses for the programme are not taught in the department. These are courses taught by the Mathematics and

Table 4 Levels of ICT application in instruction at the Teacher Education Programme in UCC

\begin{tabular}{lll}
\hline & Pre-service teachers $(\mathrm{n}=120)$ & \\
\cline { 2 - 3 } & Cronbach's Alpha=0.931 & SD \\
\cline { 2 - 3 } & $\mathrm{M}$ & 0.84 \\
\hline Word processing packages & 1.45 & 0.77 \\
Database software & 1.29 & 0.88 \\
Spreadsheet & 1.42 & 0.68 \\
Presentation Software & 1.27 & 0.61 \\
Graphical Application & 1.28 & 0.63 \\
Graphical Calculators & 1.24 & 0.65 \\
Application of multimedia & 1.24 & 0.74 \\
Use of E-mail & 1.33 & 0.80 \\
Internet & 1.37 & 0.68 \\
Use of Java Applet & 1.31 & 0.73 \\
Overall Mean & 1.32 & \\
\hline
\end{tabular}

1 Not at all; 2 A little; 3 Somewhat; 4 A lot 
Statistics Department in the faculty of Science (for both the pure sciences and the pre-service teachers); so little or no emphasis is placed on hands - on approach type of teaching. He added that most instructors at the teacher education programme continue to use traditional tools for teaching without or with a limited integration of ICT due to two main reasons: courses are not designed to integrate ICT in its delivery and lack of technology integration skills (especially related to older staff members). He emphasized that there is the need to re-design courses in the programme that will involve pedagogical content knowledge and more hands-on activities. In commenting he said: "We need to change the focus of our courses we teach in the department; they are too traditional. My vision is to promote the redesigning of courses in the department to be hands-on to enable students think better and use their hands more. So my intention is for us to move away from the traditional way of teaching". Responding to a question on whether ICT infrastructure availability and accessibility did not pose a problem for instructors' lack of ICT use, he asserted that although the department did not have an up-todate computer lab for teaching mathematics, the faculty had one which was available to instructors (particularly mathematics and science education) and was heavily under utilized. He stated: "The computers are there! If you come to the faculty, we have a whole computer Lab which is rarely used. It is because lecturers have not designed their courses to use computers. It means we have a lot to do in this area. We need to encourage lecturers to incorporate the use of computers in their delivery; but for now, the same old traditional way of teaching dominates. So even though the computers are there they are not put into use". It could be alleged from the results that the instructors' inability to use ICT in instruction is likely to have a ripple effect on these pre-service teachers in their profession since the former are their trainers.

\subsection{Professional development and training needs}

An investigation also aimed at determining mathematics teachers' overall perception towards ICT integration in lessons, training needs and willingness to participate in professional development programme that integrate ICT in instruction. Reporting on the overall perceptions of teachers' willingness to integrate ICT in lessons, an overwhelming majority of $96 \%$ (very willing $=68 \%$, willing $=28 \%$ ) pre-service and in-service teachers reported they were willing to integrate ICT in their future lessons. Only $1 \%$ said they were highly sceptical and 3\% neutral as far as ICT integration into future lessons were concerned. Table 5 shows the levels of perceptions as

Table 5 Overall perceptions of teachers towards ICT integration in delivery of mathematics lessons.

\begin{tabular}{lcc}
\hline Perception & In-service teachers $(\%)$ & Pre-service teachers $(\%)$ \\
\hline Highly sceptical & - & 2 \\
Sceptical & - & - \\
Neutral & 1 & 4 \\
Willing & 37 & 23 \\
Very willing & 62 & 71 \\
\hline
\end{tabular}


observed by the in-service and pre-service teachers respectively. The results showed that both in-service (98\%) and pre-service teachers $(94 \%)$ were very enthusiastic about integrating ICT in their future mathematics lessons.

All the 14 Hod's were enthusiastic about integrating ICT in lessons at their various schools and confirmed that mathematics teachers in their department will embrace the idea very much. One of the Hods' explained "I wish we could move from this chalk board approach to white board and effective use of ICT in instruction. It will make teaching easier and facilitate students' understanding". The Head for the teacher education programme also expressed with much emphasis the need to incorporate into the programme courses which could help pre-service teachers acquire the skill of teaching with ICT in their future profession. Specifically, he proposed that a particular course "Preparing teaching aids for mathematics teaching" taught in the final year could be re-designed to include the component of ICT. With respect to whether teachers have had the opportunity to participate in any professional development activities or not and as to which professional development needs they would want to have, Table 6 gives a summary of responses. The table shows that barely few teachers have attended any course on pedagogical issues related to integrating ICT into teaching and learning mathematics (in-service teachers $=10 \%$, pre-service teachers $=5 \%$ ) suggesting that a professional development programme for these teachers will be a step in the right direction. Data in Table 6 is supported by interview data. The officer from the ICT unit of the GES indicated that: The ICT unit was responsible for organizing trainings for teachers at the SHS but it has not been very effective. Most of the trainings have not had a focus on use of ICT as an instruction in class. Most

Table 6 Teachers' Professional development needs

\begin{tabular}{|c|c|c|c|c|c|c|}
\hline \multirow[t]{2}{*}{ Professional Development needs } & \multicolumn{3}{|c|}{ In-service $(\%)$} & \multicolumn{3}{|c|}{ Pre-service (\%) } \\
\hline & $\begin{array}{l}\text { Yes I } \\
\text { have }\end{array}$ & $\begin{array}{l}\text { No, I do } \\
\text { not wish } \\
\text { to attend }\end{array}$ & $\begin{array}{l}\text { No, I would } \\
\text { like to attend } \\
\text { if available }\end{array}$ & $\begin{array}{l}\text { Yes I } \\
\text { have }\end{array}$ & $\begin{array}{l}\text { No, I do } \\
\text { not wish } \\
\text { to attend }\end{array}$ & $\begin{array}{l}\text { No, I would } \\
\text { like to attend } \\
\text { if available }\end{array}$ \\
\hline $\begin{array}{l}\text { Technical course for operating and } \\
\text { maintaining computer system }\end{array}$ & 15.0 & 10.0 & 75.0 & 10.8 & 1.7 & 87.5 \\
\hline $\begin{array}{l}\text { Introductory course for Internet } \\
\text { use and general applications (e.g., } \\
\text { basic word-processing, } \\
\text { spreadsheets, databases, etc) }\end{array}$ & 41.7 & 23.3 & 35.0 & 32.5 & 2.5 & 65.0 \\
\hline $\begin{array}{l}\text { Subject-specific training with } \\
\text { learning software for specific } \\
\text { mathematics content goals (e.g., } \\
\text { tutorials, simulation, etc }\end{array}$ & 10.0 & 8.3 & 81.7 & 6.7 & 3.3 & 90.0 \\
\hline $\begin{array}{l}\text { Course on pedagogical issues } \\
\text { related to integrating ICT into } \\
\text { teaching and learning } \\
\text { mathematics }\end{array}$ & 3.3 & 6.7 & 90.0 & 0.8 & 3.3 & 95.8 \\
\hline $\begin{array}{l}\text { Course on multimedia operations } \\
\text { (e.g., using digital video and/or } \\
\text { audio equipment in mathematics }\end{array}$ & 5.0 & 8.3 & 86.7 & 0.8 & 5.5 & 93.7 \\
\hline
\end{tabular}


trainings have concentrated on how to help teachers get information on the internet and basic skills of computing. Again the unit is faced with the challenge of finances. As a result the TOT approach is used. This is the situation where few teachers are selected in a district to undergo training with the aim that these teachers will serve as trainers to other teachers in the same district. Unfortunately subsequent training in the various district most of the time do not take place due to improper planning. All the principals of the schools confirmed that the GES hardly organized training programmes for the schools but if they did, it focused on giving teachers basic ICT skills. The Hod's also explained that their schools did not provide any support of that kind to assist teachers integrate ICT in their instruction. Few (5 out of 14) of them however indicated that training programmes to assist teachers to acquire basic skills were offered. Two further indicated that, the training programmes were not timely and most of the time targeted fresh teachers. One of them said: "At the beginning of the academic year training is organized particularly for fresh teachers to become computer literate to equip them to be able to set their questions, key in students' results and get information from the internet."

Although responses from the teachers were high for course on multimedia (in-service teachers $=87 \%$, pre-service teachers $=94 \%$ ) and subject-specific training with learning software for specific mathematics content goals (in-service teachers $=82 \%$, pre-service teachers $=90 \%$ ) indicating that they would want to attend such courses if available, interview data from respondents were rather contrary to these views. The Hods' were of the view that more generalised software such as the spreadsheet which is user friendly could be adopted in any training to develop teachers to integrate ICT in teaching. Table 6 confirmed that the teachers (in-service $=42 \%$, pre-service $=33 \%$ ) had some knowledge in basics spreadsheet. They reported that apart from the problem of availability and accessibility of such software in the context under consideration, most mathematical applications were not known to the teachers. They concluded that the spreadsheet was known to them and can be tailored to the curriculum. One Hod explained "It will be easy for the students too because they are taught basic excel in their IT lessons so it will not be a new environment for them." The head of the teacher education programme was of the same view as the Hod's. When asked a similar question as to what application he will recommend for training of mathematics pre-service teachers in integrating ICT in their lessons, he said: "One that is not complex, easily available, the student can adopt and could be easily tailored to the curriculum". Responding to their willingness to participate in training on how to design, develop and integrate ICT for teaching mathematics, the teachers were supposed to indicate "yes", "undecided" or "no, I like to have more information". The analyses revealed that $93 \%$ (both in-service and pre-service) were willing to participate in such training, whereas $5 \%$ and $2 \%$ indicated they were not decided and would want to have more information respectively. The Hod's said their department will welcome such an innovation. One of them vehemently stated "I can confidently say yes. If there will be any problems, then it will be the very senior ones who are nearing retirement. The young ones are very enthusiastic and very interested. I am interested myself. So that much, I can give you the assurance that such a program will be well patronized". 


\section{Discussion and conclusions}

Despite the positive policy statements regarding the need for technology in Ghanaian Senior High Schools, and in the mathematics curriculum in particular, the implementation of technology in educational practice will be a major effort. In this study we explored the barriers, learning needs and opportunities for preparing mathematics teachers to integrate ICT in their instructions. We collected data from in-service teachers who were teaching in schools which had a relative good technology infrastructure. This choice was made because we expect that these schools (and their teachers) will be the first ones to implement the ambitions of the Ghanaian government regarding technology integration in the Senior High School. This is also confirmed by the school principals that were interviewed as part of the study. Also we collected data from pre-service teachers. To realize the implementation of technology, pre-service teachers need to be well prepared to use technology in their future teaching. For this reason we invited pre-service teachers from one of the two main teacher education institutions to participate in the study. Although findings from this study can not be generalized to Ghanaian in- and pre-service mathematics teachers, we believe that they provide information about conditions and opportunities to realize the first steps in the process of implementation of technology in Senior High Schools. Fullan (2007) indicated that school-based professional community can offer support and motivation to teachers as they work to overcome the tight resources, isolation, time constraints and other obstacles they commonly encounter in today's schools. He maintains that within a strong professional community, for example, teachers can work collectively to set and enforce standards of instruction and learning. The results showed a number of barriers identified to be reasons why mathematics teachers in this study did not integrate ICT in their instruction. Among others, lack of ICT knowledge in integration: lack of knowledge about ways to integrate ICT in lesson and lack of training opportunities for ICT integration knowledge acquisition (Ottevanger et al. 2007; Snoeyink and Ertmer 2002; Jones 2004) were the major perceived barriers identified by both group of teachers. Particularly, the pre-service teachers in this study reported fairly lower attitudes about knowledge of technology use in instruction than the in-service teachers. In-service training programmes organised for in-service teachers as was reported by school heads could explain this difference. Lack of ICT infrastructure (Snoeyink and Ertmer 2002; Jones 2004) were also reported by the participant to be real challenges faced in the mathematics classrooms in Ghana. The study showed that schools lacked common mathematical software (such as derive, graphic calculus, geometer's sketchpad etc) used in teaching mathematics. It was particularly surprising to find that no classroom was identified to be web-based although few computer laboratories were supported by internet connectivity. Low ICT access levels as reported by the teachers are possible barriers for their inability to integrate ICT in instruction. Similar study conducted in Ghana (Agyei and Voogt, submitted) reported low levels of ICT integration of these teachers as a result of their low ICT competencies and access levels. Another barrier to ICT integration as reported by the teachers was the teaching strategy used in SHS's. The most frequently used strategy for teaching as reported was the chalk and talk approach (Ottevanger et al. 2007; Ampiah et al. 2004); in which teachers did most of the talking and intellectual work, 
while students were passive receptacles of the information provided. Both in- and pre-service teachers barely differed in opinions on this subject. These teachers also have been taught in the same manner and for most of them effectively integrating ICT in their instruction is a complex innovation (AACTE 2008; Voogt 2008) which requires them to change their routines of teaching. This was reiterated by the preservice teachers who reported that most instructors at the teacher education programme were mainly dependent on lecture-based instruction. The programme also did not include courses where teachers were taught how to integrate ICT in their lessons (Adamy and Boulmetis 2006; Brown and Warschauer 2006). This means that the pre-service teachers' experience to integrate ICT in teaching is limited making the programme fall short of the practical approach. This leads to the big question whether the presently trained pre-service teachers are sufficiently prepared for new teaching methods which are flexible and involve appropriate use of technology. The teachers also indicated that although schools are generally interested in ICT use, regular school practices did not promote ICT use in classrooms. Most in-service teachers reported that schools did not offer them sufficient time to manage and familiarise themselves with ICT. They maintained that as well as lack of time, schools did not provide support network for them to take up the challenges of using ICT in teaching. An additional barrier that could have contributed to these teachers use of ICT was the curriculum factor. Although the curriculum requires mathematics teachers to use ICT in instruction, some teachers (especially in-service ones) alleged that the current status of the curriculum presented serious threats to possibilities of teaching to integrate ICT in the classroom. As a result most of them reinforce the phenomenon of "teaching to the test" where they rush to cover all the topics mechanically in order to finish on time for examinations rather than striving for in depth student learning. Thus they contended that, to allow for meaningful teaching by integrating ICT, the concern of curriculum overload should be addressed.

In spite of the barriers, the study also showed several opportunities that existed for the teachers to be trained to be able to integrate ICT in their teaching. Curriculum (MOESS 2007; MOE 2000) and Policy documents (Ghana ICT4AD Policy 2003) highlight the importance of integrating ICT to enhance teaching and learning. The teacher education programme and SHS's are open to any such ICT innovation. Both in- and pre-service teachers expressed the need for mathematics teachers to integrate ICT in their lessons. More importantly they showed a lot of enthusiasm to be part of any professional development programme related to integrating ICT in teaching and learning mathematics. It was encouraging to find that contemporary mathematics teachers appeared generally supportive and confident in wanting to use computers in their classrooms. Their overwhelming high perceptions (more especially the inservice teachers) to integrate ICT in an innovative way to improve teaching in their future lessons confirmed this. This is in line with similar study (Authors; in preparation) which reported positive attitudes of these teachers towards ICT integration which is a necessary condition for teachers' willingness to participate in an ICT related programme and a predictor of future classroom integration (Authors; in preparation). Although the study reported overall low ICT infrastructure and accessibility in the schools, it could be argued that with computer numbers in schools having increased, the access difficulties identified are likely to stem from a situation in which demand outstrips supply rather than simply a shortage of 
hardware; although this may be the case in some SHS's in other parts of the country. This augurs well for the future with respect to the design of a professional development programme and anticipated levels of computer competence and its use among new, younger, mathematics teachers as they enter the profession.

The findings reported here highlight areas that require further attention to enable teachers use ICT in mathematics teaching. In particular, a professional development scenario that will assist pre-service and in-service teachers develop skills on ways to integrate ICT in their teaching processes was one of the significant issues identified by the researchers. Such a programme need not differ in content but in format for both groups of teachers. Bearing in mind the complexity of the problems most mathematics classroom in Ghana face in terms of ICT infrastructure and lack of application software, an environment with a more generalised application that offer a technology readily available and user friendly among mathematics classroom with the potential for supporting students' higher-order thinking in mathematics (such as spreadsheet) is proposed for use in professional development programmes. This will ensure that teachers will be able to use existing hardware and software in creative and situation specific ways to design ICT resources to accomplish their teaching goals. Thus this study is in line with SMICT study (Ottevanger et al. 2007) which discusses the lessons for improving teaching and learning mathematics in secondary education in Africa. Among their recommendations, effective use of ICT needs to be optimized through extensive programmes of teacher support to improve mathematics and science teaching in Sub-Saharan Africa.

Open Access This article is distributed under the terms of the Creative Commons Attribution Noncommercial License which permits any noncommercial use, distribution, and reproduction in any medium, provided the original author(s) and source are credited.

\section{References}

AACTE Committee on Innovation \& Technology (Ed.). (2008). Handbook of Technological Pedagogical Content Knowledge (TPCK) for Educators. New York and London: Taylor and Francis Group.

Adamy, P., \& Boulmetis, J. (2006). The impact of modeling technology integration on pre-service teachers' technology confidence. Journal of Computing in Higher Education, 17(2), 100-120.

Adu-Gyamfi, D., \& Smit, C. P. (2007). Programme Reform and Alignment for increasing Competencies of Teachers and for Improving Comprehension and Application in Learning science and mathematics (PRACTICAL): an inception report on the Analysis of standards in subject content mastery in B.Ed programmes in Ghana. Centre for International Cooperation (CIS), Vrije Universiteit Amsterdam.

Ampiah, J., Akyeampong, A. K., \& Leliveld, M. (2004). Science, mathematics and ICT (SMICT), secondary education in sub-Saharan Africa - country profile Ghana. Centre for International Cooperation (CIS), Vrije Universiteit Amsterdam.

Anamuah-Mensah National Education Review Committee Report. (2002). Report of the President's Committee on Review of Education Reforms in Ghana. Accra: Ministry of Education.

British Educational Communications and Technology Agency (BECTA) (2003). What the research says about using ICT in maths. Retrieved 19th June, 2008 from www.becta.org.uk/research.

Brown, D., \& Warschauer, M. (2006). From the university to the elementary classroom: students' experiences in learning to integrate technology in instruction. Journal of Technology and Teacher Education, 14(3), 599-621.

Clements, D. H. (2000). From exercise and tasks to problems and projects- unique contributions of computers to innovative mathematics education. The Journal of Mathematics Behavior, 19(1), 9-47. 
Fullan, M. (2007). Leading in culture of change. San Francisco: Jossey- Bass.

Ghana ICT4AD Policy. (2003). A Policy statement for the realization of the vision to transform Ghana into an information-rich knowledge-based society and economy through the development, deployment and exploration of ICT's within the economy and society. Accra: Ministry of Education.

Hennessy, S. (2000). Graphing investigations using portable (palmtop) technology. Journal of Computer Assisted Learning, 16, 243-258.

Hennessy, S., Fung, P., \& Scanlon, E. (2001). The role of the graphic calculator in mediating graphing activity. International Journal of Mathematics for Education in Science and Technology, 32(2), 267290.

Ittigson, R. J., \& Zewe, J. G. (2003). Technology in the mathematics classroom. In L. A. Tomei (Ed.), Challenges of teaching with technology across the curriculum: Issues and solutions (pp. 114-133). Hershey: Information Science Publishing.

Jones, A. (2004). A review of the research literature on barriers to the uptake of ICT by teachers. UK: Becta.

Miles, M. B., \& Huberman, A. M. (1994). An expanded source book, qualitative data analysis (2nd ed.). London: SAGE Publications.

Ministry of Education. (2000). Teaching syllabus for mathematics. Accra: Ministry of Education.

Ministry of Education, Science and Sports (MOESS). (2007). Teaching syllabus for mathematics. Accra: Ministry of Education.

Mishra, P., \& Koehler, M. J. (2006). Technological pedagogical content knowledge: a framework for integrating technology in teacher knowledge. Teachers College Record, 108(6), 1017-1054.

Moseley, D., \& Higgins, S. (1999). Ways forward with ICT: Effective pedagogy using information and communications technology for literacy and numeracy in primary schools. London: Teacher Training Agency.

Mullis, I. V. S., Martin, M. O., Gonzalez, E. J., \& Chrostowski, S. J. (2004). International mathematics report: Findings From IEA's trends in International Mathematics and Science Study at the fourth and eighth grades. Chestnut Hill: TIMSS \& PIRLS International Study Center, Boston College.

Mullis, I. V. S., Martin, M. O., \& Foy, P. (2008). International mathematics report: Findings from IEA's trends in International Mathematics and Science Study at the fourth and eighth grades. Chestnut Hill: TIMSS \& PIRLS International Study Center, Boston College.

Ottevanger,W., van den Akker, J. J. H., \& de Feiter, L. (2007). Developing Science, Mathematics and ICT education in Sub-Saharan Africa (SMICT): Patterns and promising practices, World Bank Working Paper (101), pp. 1-84.

Snoeyink, R., \& Ertmer, P. A. (2002). Thrust into technology: how veteran teachers respond. Journal of Educational Technology Systems, 30(10), 85-111.

Voogt, J. (2008). IT and curriculum processes: Dilemmas and challenges. In J. Voogt \& G. Knezek (Eds.), International handbook of information technology in primary and secondary education. New York: Springer. 